\title{
HUBUNGAN LAYANAN SIRKULASI DENGAN \\ PEMBENTUKAN CITRA PERPUSTAKAAN \\ (STUDI DESKRIPSI DI PERPUSTAKAAN UNIVERSITAS \\ ANDALAS)
}

\author{
Rifan Irfandi \& Habiburrahman \\ email: rifanirfandi@gmail.com
}

\begin{abstract}
Circulation services, in English circulation is "circulation", which is a round in the world of libraries, this service division serves as a lending service and a customer service. In the world of libraries, this service is very important, therefore the services in this section require library management personnel to be equipped with knowledge and skills in managing libraries, especially in the circulation services section. From this description, it can be concluded that circulation services are activities that must be in the library related to the borrowing and returning library materials so that they can be used optimally by users. This circulation service aims to make the use of collections effective and the control of collections in the library can be considered because they can know when the users borrow and return the collections borrowed from the library, therefore the collections can be performed well. If the user is late in returning the collection, he will be subject to a fine that has been agreed upon and determined by the library.
\end{abstract}

Kata kunci : Circulation; Library; Librarian

\begin{abstract}
Abstrak
Layanan sirkulasi, dalam bahasa Inggris sirkulasi ialah "circulation" ialah putaran di dunia perpustakaan bagian layanan ini bertugas untuk sebagai pelayanan peminjaman dan pelayanan pemustaka. Di dalam dunia perpustakaan layanan ini sangatlah penting oleh karena itu layanan yang ada bagian ini. Untuk itu membutuhkan tenaga pengelola perpustakaan perlu dibekali pengetahuan dan keterampilan mengelola perpustakaan
\end{abstract}


khususnya pada bagian pelayanan sirkulasi. Dari uraian tersebut bisa disimpulkan bahwa pelayanan sirkulasi adalah kegiatan yang harus ada di dalam perpustakaan yang berhubungan dengan bagian peminjaman dan pengembalian bahan pustaka agar dapat dipergunakan oleh pengguna secara maksimal. Layanan sirkulasi ini bertujuan agar pemakaian koleksi bisa efektif dan pengawasan terhadap koleksi di perpustakaan bisa diperhatikan karena bisa tau kapan pemustaka meminjam dan mengembalikan koleksi yang di pinjam di perpustakaan oleh karena itu koleksi dapat kerja dengan baik. Jika pemustaka tersebut terlambat mengembalikan koleksi maka akan dikena denda yang telah disepakati dan ditetapkan oleh perpustakaan tersebut.

Kata kunci : Sirkulasi; Perpustakaan; Pemustaka 


\section{A. Pendahuluan}

Perpustakaan umum adalah perpustakaan yang diperuntukkan bagi masyarakat luas sebagai sarana pembelajaran sepanjang hayat tanpa membedakan umur, jenis kelamin, suku, ras, agama, dan status sosial-ekonomi.perpustakaan juga berguna untuk menyimpan koleksi-koleksi hasil dari pemikiran manusia seperti contoh skripsi, tesis, disertasi dan masih banyak yang lainnya. Sejarah perpustakaan di Indonesia tergolong masih muda jika dibandingkan dengan negara Eropa dan Arab. Jika mengacu pada dasar pemikiran bahwa sejarah perpustakaan ditandai dengan dikenalnya tulisan, maka sejarah perpustakaan di Indonesia dimulai pada tahun 400-an, yaitu saat lingga batu dengan tulisan Pallawa ditemukan dari periode Kerajaan Kutai. Pada tahun 414, musafir Fa Hsien menyatakan bahwa di kerajaan Yepoti (yang sebenarnya kerajaan Tarumanegara), banyak dijumpai kaum Brahmana. Kaum Brahman memerlukan buku atau manuskrip keagamaan yang kemungkinan disimpan di kediaman pendeta.

Layanan sirkulasi, dalam bahasa Inggris sirkulasi ialah "circulation" ialah putaran di dunia perpustakaan bagian layanan ini bertugas untuk sebagai pelayanan peminjaman dan pelayanan pemustaka. Di dalam dunia perpustakaan layanan ini sangatlah penting oleh karena itu layanan yang ada bagian ini. Untuk itu membutuhkan tenaga pengelola perpustakaan perlu dibekali pengetahuan dan keterampilan mengelola perpustakaan khususnya pada bagian pelayanan sirkulasi. Dari uraian tersebut bisa disimpulkan bahwa pelayanan sirkulasi adalah kegiatan yang harus ada di dalam perpustakaan yang berhubungan dengan bagian peminjaman dan pengembalian bahan pustaka agar dapat dipergunakan oleh pengguna secara maksimal. Layanan sirkulasi ini bertujuan agar pemakaian koleksi bisa efektif dan pengawasan terhadap koleksi di perpustakaan bisa diperhatikan karena bisa tahu kapan pemustaka meminjam dan mengembalikan koleksi yang dipinjam di perpustakaan oleh karena itu koleksi dapat kerja denan baik. Jika pemustaka tersebut terlambat mengembalikan koleksi maka akan dikena denda yang telah disepakati dan ditetapkan oleh perpustakaan tersebut. 
Citra merupakan kesan atau gambaran terhadap sesuatu objek baik itu berkesan positif atau negatif nantinya. Citra perpustakaan bisa disebut gambaran dan penilaian dari masyarakat atau pemustaka yang pernah berkujung dan merasakan pelayanan yang ada di perpustakaan tersebut. Semua instansi atau perusahaan memiliki pasti memiliki citranya masing-masing.

\section{B. Hasil Penelitian}

Penelitian ini menggunakan penelitian kualitatif. Menurut Crosswell (Andi Setiawan, 2019) metode penelitian kualitatif menuntut peneliti untuk mengambil kesimpulan dari hasil pandangan yang diperoleh dari para partisipan. Pengumpulan data dilakukan melalui observasi, wawancara, dan dokumentasi. Instrumen penelitian meliputi peneliti sendiri, pendoman wawancara, dan catatan lapangan. Teknik penentuan informan menggunakan purposive sampling. Teknik analisis data meliputi menurut Sugiyono (Nduet, 2019) ada tiga, yaitu :Reduksi data, penyajian data, verification/kesimpulan.

\section{Pembahasan}

\section{Layanan Sirkulasi di Universitas Andalas}

Layanan sirkulasi bertanggung jawab atas peminjaman dan pengembalian koleksi yang dilakukan pemustaka atau anggota pustaka yang ada di dalamnya. Setiap perpustakaan sudah dipastikan memliki layanan sirkulasi karena layanan sirkulasi sangat berperan penting di suatu perpustakaan. Begitupula dengan perpustakaan universitas Andalas yang juga memiliki layanan sirkulasi. Pada layanan sirkulasi di Universitas Andalas mempunyai kebijakan yaitu buku kolesi perpustakaan boleh dibawa pulang dengan cara dipinjam baik itu peminjaman mandiri atau peminjaman yang dilakukan kepada pustakawan dengan jangkauan waktu yang telah ditentukan. Layanan ini telah dilengkapi dengan sistem peminjaman mandiri. Dengan sistem ini pemustaka dapat langsung melakukan transaksi peminjaman buku melalui anjungan mandiri. Setelah melakukan transaksi, pemustaka memperlihatkan print out bukti transaksi kepada petugas. Layanan sirkulasi di perpustakaan Unand ini sendiri berada di lantai 1 gedung perpustakaan. Di bagian 
ruangan layanan sirkulasi ini telah dilengkapi dengan fasilitas internet. Koleksi yang ada di layanan referensi perpustakaan Unand anatara lain:

a) Ensiklopedia

b) Buku Ajar. Koleksi tersebut juga bisa akses secara online dengan cara membuka website E-Book dan E- Ensiklopedia

\section{Fungsi dan Tugas Layanan Sirkulasi di Perpustakaan Unand}

Hasil dari penelitian dan wawancara yang dilakukan di bagian layanan sirkulasi perpustakaan Universitas Andalas sebagai berikut:

a) Untuk melayani pemustaka dalam perihal peminjaman dan pengembalian koleksi.

b) Membantu pemustaka dalam mencari koleksi yang ia butuhkan.

c) Mengawasi dan menjaga koleksi yang ada di perpustakaan karena layanan sirkulasi menjadi bagian paling penting di perpustakaan karena pengembalian dan peminjaman koleksi melalui bagian sirkulasi.

d) Berhak menerima uang denda ataupun penganti koleksi yang hilang dari hasil keterlambatan pengembalian koleksi bagi pemustaka.

\section{Strategi meningkatkan layanan sirkulasi agar mendapatkan citra yang baik}

Layanan sirkulasi sangat penting dalam tubuh perpustakaan jika baik pelayananan terhadap pemustaka dan lengkap koleksi nya akan sangat berpengaruh karena akan mendapatkan nilai positif dari para pengunjung perpustakaan. Bagaimana langkah atau strategi untuk meningkatkan pelayanan sirkulasi di perpustakaan Universitas Andalas sebagai berikut :

a) Memberikan pelayanan prima dengan keramahan yang dilandasi dengan kode etik pustakawan yang telah ditetapkan.

b) Membantu pemustaka dalam mencari serta menelusuri koleksi yang dicarinya.

c) Memberikan pemahaman dalam pengunaan teknologi yang ada di perpustakaan seperti contohnya OPAC. 
d) Memberikan kesan positif kepada pemustaka dan pengunjung ke perpustakaan.

e) Dapat berkomunikasi dengan baik kepada pemustaka dan mampu menjalin hubungan baik dengan antar pustakwan agar meningkatkan kinerja perpustakaan tersebut.

\section{Daftar Pustaka}

Arafat. (2006). Pengertian Citra . 29.Lasa. (1994).

Mita Aresti, H. (2019). Upaya Mewujudkan Ruang Publik Bgai Tunanetra di Balai Layanan Perpustakaan Unit Grhatama Pustaka Daerah Istimewa Yoghyakarta. Jurnal Ilmu Perpustakaan, 40-48.

Palupi, A. s. (2003). Pengertian perpustakaan.

Pengertian Pelayanan Sirkulasi Menurut Abli. (2015, Agustus 31). Retrieved Januari 09, 2021, from lampungtimur.com: lampungtimur.com/2015/08/pengertianpelayanan-sirkulasi-menurut.html

PUTRA, F. R. (2016, Mei 16). pelayanan sirkulasi perpustakaan . Retrieved Januari 9, 2021, from basipda.bekasikab: https://basipda.bekasikab.go.id/berita-pelayanansirkulasi-perpustakaan.

Sulistyo-Basuki. (1993).

Yendri. (2010). 